Research.

\title{
The effect of budgeting based on performance upon the accountability of authority administration of Bogor municipality performance period 2014-2017
}

\author{
Agung Fajar IImiyono \\ Department of Economic, Pakuan University, Bogor, Indonesia \\ agung.fajar@unpak.ac.id
}

Received: August 12, 2019; Accepted: November 7, 2019; Published: December 31, 2019.

To cite this article: Ilmiyono, Agung Fajar. (2019). The Effect of Budgeting Based on Performance upon The Accountability of Authority Administration of Bogor Municipality Performance Period 2014-2017. The Accounting Journal of Binaniaga. 4 (2): 01-08. doi: 10.33062/ajb.v4i2.337

\begin{abstract}
Budgeting based on performance is a type of budget used in public sector activities. This type of budget is influenced by environmental factors that must be predicted to determine the level of uncertainty high or low, so that the objectives for implementing financial reporting performance accountability can be achieved. The purpose of this study is to determine the effect of Budget Planning on Performance Accountability of Bogor municipality administration, to determine the effect of Budget Implementation on Performance Accountability of Bogor municipality administraion and to determine the effect of Performance Evaluation on Performance Accountability of Bogor municipality administration. This research was conducted at the scope of the Bogor municipality administration. This research was conducted at the scope of the Bogor municipality administration. The analytical method used is sample test $t$ and multiple linear regression. the sample chosen using a random sampling method taken from 10 units of the Bogor City Regional Work Unit (SKPD) consisting of 50 respondents. The results of the study showed that Budget Planning and performance evaluation have a positive and significant effect on the Accountability of the Performance of Bogor municipality administration. While Budget Implementation does not affect the Accountability of Performance of Bogor municipality administration..
\end{abstract}

Keywords: Budget Planning, Budget Implementation, Performance Evaluation, and Performance Accountability

\section{Introduction}

Budget is an important thing to be considered within an organization. In the private organization, budget is confidential, but in the public sector it has to be declared to the public, to be evaluated, to be critized and to be adviced in order to improve the government authority performance. The issuances of Acts Number 23 year 2014 and Acts number 33 year 2004 have been changing the district financial management which has created the reformation of district financial management. The district financial management has to be executed transparently and accountably complying to the applicable regulation to control the district finance. Inspite of district financial management system has been changed, those aforementioned acts have changed the accountability and reposnsibility of district authority which is instead of being responsible for the Central Governement it has to be responsible for the people of the district area thru DPRD (District Representative) 
The issuances of Acts No.33 year 2004 and Acts No.23 year 2014 have obliged the authority to be accountable and concerned about budgeting, accounting control and reporting system.. Acts No. 17 year 2003 regarding government finances which has stipulated that the application of budgeting must be based on performance approach in designing a budget which is important to make budgeting process better. As well as the regulation of budgeting application based on performance that is mentioned on the Regulation of the Minstry of Home Affairs No. 59 year 2007 regarding Guideline of District Finance Management. This regulation has stated Designing Job Plannng and Budgeting of District Work Unit Requirement (RKA-SKPD)

The Government Regulation of the Republic of Indonesia No.8 Year 2006 has stipulated that Finance report is a responsibility of managing government/regional/district financial for a certain period, performance is the output/result of the activities reaching the achievement of using the budget which can be measured either quantitatively and qualitatively. Performance Report is an overview describing succinctly and completely the performance achievement which is prepared based on Work Planning and is in compliance with the guideline of APBD/APBD. Budget is the most relevant and crucial thing in the government authority because it has been showing government accountability obviously. It is related to the government function to provide public service. Since the responsibility has changed from vertical responsibility to horizontal responsibility, it has required DPRD to control the authority performance based on the budget absolutely.

Budgeting system of public sector has been becoming an instrument of multifunction policies applied as the tools to reach the organization goals. As a system, the planning of public sector budgeting has been developing accordingly. The system of public planning has been developing and changing according to the dinamics of the development of public sectors management and public requirements appeared. As a matter of fact there are some approaches in the planning and organizing the budget of public sectors appeared. However, there are two main approaches having fundamental differences absolutely. Those two kind approaches are: (a) Traditional or Conventional Budget and (b) New Pubblic Management Budget. Along with this development, some budgeting technique of public sectors have been coming up, for example: Budgting Performance, Zero Based Budgeting (ZBB), and Planning, Programming and Budgeting System (PPBS). Budgeting reformation done by the government has changed budgeting structure as well as APBD budgeting process which has developed the transparency of budgeting and have increased public accountability. Budgeting reformation has improved the process of budget which is the emplementation of budgeting based on performance.

Budgeting based on Performance is a budgeting system oriented to the output of an organization and related tightly to the vision, mission and strategic planning of the organization (Bastian, 2010). It has focused to the concept of value for money and controlling the performance output. Budgeting based on Performance has been prepared in order to try to overcome some weaknesses of traditional budgeting, especially weakness of unapplicable measuring tool to measure the performance of objectives and goals achievement of public service (Mardiasmo, 2018). Budget which is not either effective nor oriented to the performance will jeopardize the planning prepared. A Continuous Performance Measurement will provide the feedback accordingly, nevertheless, a continuous improvement will make future achievement successfully (Bastian, 2010)/

Budgetting based on Performance is to improve the allocation of the resources efficiently and effectively according to the planning designed by the district authority, budget can be used optimum to increase the society welfare and to support the transparency and accountability of public sectors management, nevertheless, budgeting based on performance has concentrated on the usage of budget to improve the organization performance refered to Value for Money. The implementation of this budgeting based on performace in Indonesia has encountered some difficult challenges because it will change completely budgeting system obviously. The most difficult challenges are how to change people mind-set which is not only in the authorities 
department (executives) but also in the House of People Representatives(DPR) as the legislative institution which is having legislative mindset in discussion and stipulation of APBN (state budget) that is expected can change input basis to output basis

Designing regional/districts budgeting in Bogor city has been started from KUA and PPAS design which is stated on the MOU of PPA between Chief of District and DPRD, afterthat, a circulation letter will be prepared and distributed to each district head to be used as the guideline of preparing RKA-SKPD program and activites proposed in the related year. Furthermore, it has to design the draft of district regulation about APBD(district budgeting) and draft of district head regulation regarding the description and distribution of APBD, then an evaluation of those both drafts has to be done accordingly, when they are accepted, they will be stated as the applicable regulation regarding APBD and regulation of district head

Budget in the government administration is not only as the tools to design and to control, but also as the instrument of public accountability to manage public finance as well as the execution program financed by public finance(Bahri, 2012). Budgeting system in Bogor City Administration has been prepared according to the process of budgeting based on performance. Implementation of budgeting based on performance is expected that the budget designed by the authority can be executed properly which is in accordance with the goals to be achieved. As a matter of fact, there has not proper achievement happened yet between budget to finance the program decided and the actual budget spending. It described the discrepancy between budget and actual spending that had explained that APBD preparation did not comply with the applicable regulation indicating that the program of the activities had not been implemented completely yet.

Based on the data of Bogor APBD 2014-2015 indicated that budget spending to finance the program had increased, but in 2016 budget spending had decreased, however, it increased again in 2017, unfortunately increasing budget was not compensated by the increasing of performance, nevertheless, it had been described on the performance achievement prescribed in LAKIP of Bogor in 2014-2015 indicated that performance program achievement of $2014-2015$ was $71.52 \%, 69.87 \%$, it explained that performance had decreased $1.65 \%$. but in 2015-2016 performance achievement showed $69.87 \%, 73.22 \%$ it explained that the performance had increased $3.35 \%$ and in 2016 2017 it indicated the performance achievement of $73.22 \%, 52 \%$ it was indicating that performance had decreased $21.22 \%$. However, it does not mean that the program is not good.

Performing the performance evaluation, we have to see also its indicator, for example, an indicator of increasing the quality of education management is happened when the average figure shows $102.75 \%$. Percentage unit of education which had received the facility and infrastructure support in 2015 was $122.85 \%$ and balance of the budget was Rp 239,556,263,351.-. Having sufficient balance of the budget has been compensated with the indicator of achievement, however, it has explained that the performance of increasing access and education quality management is very good.

Based on the description above, the writer is interested in doing a research with the title of "The Effect of the Implementation Budgeting based on Perfomance upon the Accountability of Bogor Municipality Administration Performance for the period of 2014-2017".

Aims of this research are as follows:

1. To find out whether budgeting preparation has affected the accountability of Bogor Authority Administration Performance.

2. To find out whether the execution of budget has affected the Accountability of Bogor Authority Administration Performance.

3. To find out whether performance evaluation has affected the Accountability of Bogor Authority Administration. 


\section{Library Review}

Budgeting based on Performance actually is a budgeting system which is output oriented. Referring to Abdul Hakim(2007) "budgeting based on performans is budgeting method for the management to corelate budget decided with the activities and the result/output expected which is achievement of the output efficiently, Output and the result expected has been designed on the performance target for each performance unit". Bastian(2010) indicated that budgeting based on performance is budgeting system which is output oriented related to vision, mission and strategic planning of the organization. Solihin, Bappenas (2007) described budgeting based on performance is a budgeting based on the job performance consisting of program and activities which will be executed and performance indicator to be achieved by a budgeting entity" But on the Acts No.17 year 2003, it is explained that budgeting based on performance is "a kind of approach in designing the budget based on job performance that will be achieved."

Based on the theories above, budgeting based on performance is the policy instrument containing one or more activities which will be performed by the government authority to reach the goals and objectives as well as to get the allocation of budget or public activities coordinated by the authority which is published by Renja-SKPD at each unit of work within a unit of authority administration which is responsible for the budget benefit for DPR and public.

1. Budgeting

In order to make the development activities work efficient, effective and target achievment, the national development planning and regulation uniformity are required to reach the government goals and to avoid interarea imbalance. Regulation regarding national development planning system covering macro planning or national policy level at all authority functions which is integrated with the living of the people in the area of Republic of Indonesia regulated in the Acts No.25 year 2004. regarding National Development Planning. District Budget Planning which has covered general policy of APBD design consisting of the step of district budgeting planning process. Refered to the Acts no. 17 year 2003 and No. 33 yea 2004 and No. 23 year 2014

\section{Budget Execution}

All district revenue and spending which is in relation with the execution of district administration affairs are stipulated on the APBD. APBD execution is covering budget, revenue and spending. Budget execution done by Head of SKPD after being stipulated by PPKD approved by the Secretary of the District Authority. This execution has involved much people which is preparation, feedback from the expert accordingly. Therefore, budget execution has to: (a) guarantee that the budget will be executed is in accordance with the responsibility given either in finance aspect or policy aspect. (b) comply with budget execution policy refers to macro economy changes (c) decide whether a problem has come up during the implementation of the bugget. (d) be in charge of purchasing and using the resources efficiently and effectively. Budget execution system has to be able to guarantee that they are fully in charge of budget implementation and the managers can do it more flexible.

3. Job Performance Evaluation.

Job performance is to evaluate either an achievement or a failure during job execution done by the incumbent.. The aims of job performance evaluation is to check the organization achievement whether there are some problems coming up or not.

Accountability is people responsibility upon their organization refers to their reporting about their achievement periodically. Resources are supporting tools given to people or units to ease their job execution. The resources above are refered to human resources, finance, infrastructures. equipments and working method. Natural 
resources are connected with government, authority administrator, environment, legals and politics. The Decree of Head of LAN No. 239/IX/6/8/2003 regarding guideline to prepare a periodic reporting about the accountability of authority job performance describing that accountability of authority administrator is measured according to the achievement of job and responsibility of the authority administration given.

Refering to the description above, accountability is the achievement of someone's job execution given to reach the goals of the organization which is covering resources management and reporting done periodically based on the papers requirements.

\section{Research Methodology}

This research has applied Explanatory Survey method to examine hypotheses, in general it is the research describing a correlation of 2 or more variables. Object of the research is the implementation of budget based on performance as an independent variable affecting the Accountability of Authority Administration job performance in Bogor municipality as dependent variable. Unit of analysis has applied regional geography which is an area/district/regional/state to get the data of a specific area/district/state. Location of the research is where the research has been done which is The Authority Administration of Bogor Municipality. Data application has used quantitative data as primary data using questionnaires given to the repondents to reply the items of the questions related to 4(four) instruments of the research, which is budgeting based on performance being measured by the three variables, Budgeting, budget execution, job performance evaluation and the accountability of authority administration performance. Data of the research are subjective data which is opinion, attitude, experience, characteristic of the respondent. Population of the research is SKPD(Working Unit of District Aparaturs) at Bogor Municipality, consisting of 10 samples of SKPD and 50 respondents, and the method has applied simple random sampling taken at any level of position to give the information required by the researcher. Data primary of this research is respondent's perception about the variables offered thru the questionnaires distribution. This questionnaires are consisting of some questions distributed to Working Unit of District apparaturs(SKPD)

Each questionnaires distributed to the respondents was introduced by covering letter. Analysis has applied quantitative analysis since the data applied is primary data refers to interviewing, questionnaires distribution discovering research variable behavior which declares data of the respondents reply. And data obtained from the respondents were calculated its percentage. Analysis methods to examine the data are validity test, reliability test, classic assumption test, multiple linear regression test, and hypotheses test.

\section{Result and Description.}

Based on the result of the research done by the writer regarding the effect of the implementation of budgeting based on performance upon the accountability of the performance of Authority Administration using three variables, budgeting variable, budget execution variable, and performance evaluation variable, the writer has interpreted the following result of the research:

1. Based on partial test which had been done between Budgeting (X1) aganst the Accountability of the performance of Authority Department $(Y)$, result of multiple linear regression test showed the coefficient value of variable $\mathrm{X} 1$ of 0.740 which means variable $\mathrm{X} 1$ has affected positively the accountability of Bogor municipality authority administration performance. Result of hypotheses test of $t$-count for 
variable budgeting is 5.642 and sig.value of 0.000 which is less than error(a) of $5 \%$ or 0.05 it is concluded that budgeting has affected significantly the accountability of Bogor municipality authority administration performance. The result above has proved that hypothesis of $\mathbf{H 1}$ is accepted describing that budget has positively and significantly affected the accountability of authority administration performance in Bogor municipality.

2. Based on partial test which had been done upon Budgeting Execution (X2) against the Accountability of Authority Administration $(Y)$ indicating result of multiple linear regression test showed coefficient value of variable X2 of -0.293 which means that variable X2 had negatively affected the accountability of Bogor authority administration performance, budget execution had shown t-count value of -0.732 and sig.value of 0.468 which was bigger than error (a) of $5 \%$ or 0.05 , so that, it was concluded that budget execution did not affect significantly the accountability of bogor authority administration performance. The result above has proved that hypotheses of $\mathrm{H} 2$ is rejected which means that budget execution has not affected significantly the accountability of bogor authority administration performance.

3. Based on Partial Test between Budget Perfomance Evaluation (X3) and the Accountability of Government Authority Administration Performance (Y), result of multiple linear regression test has shown coefficient value variable X3 is 0.758 which means variable X3 has positively affected the Accountability of Bogor Authority Administration performance. Performance evaluation has indicated $\mathrm{t}$-count value of 2.786 and sig.value of 0.008 which is less than error (a) of $5 \%$ or 0.05 , so that, it is concluded that performance evaluation has significantly affected the accountability of Bogor Authority Administration performance. The result above has proven that hypotheses $\mathrm{H} 3$ is accepted which means that performance evaluation has positively and significantly affected the accountability of Bogor authority administration performance obviously.

\section{Conclusion and Suggestions}

This research aims to recognize the Effect of Budgeting based on Performance upon th Accountability of Government Authority Administration Performance (Study at Authority Administration of Bogor Municipality) using four variables, Budgeting, Budget Execution and Performance Evaluation. The examination of effect of independent variables upon dependent variable which has been discussed above, the writer has concluded that:

1. Budgeting has positively and significantly affected the Accountability of Authority Administration performance since the planning to define working program is measurable, documentation of General Budgeting Policy (KUA) which is refered to RKPD document, budgeting steps is in compliance with budgeting policy which is measurable and is in line with vision, mission of Bogor Municipality Administration.

2. Budget Execution has not affected the Accountability of Authority Administration performance since in budget execution, SKPD has to be in accordance with budget execution documentation and Cash budgeting that had been approved. SKPD has to follow the procedure of revenue and spending based on the amount stated. however, during the execution of bogor municipality budget has not yet complied with the budget decided, such as, activity goals which has not achieved the target as mentioned on the report of budget realization of Bogor municipality as well as budget has not been equal with the performance stated on LRA and LAKIP, It has been explaining that budget execution is not in compliance with the planning, and bogor municipality has not yet implemendted Budgeting based on Perfomance properly and accountably.

3. Performance Evaluation has positively and significantly affected the Accountability of Authority Administration Performance, since.the execution of Performance Evaluation to achieve the target which is mission achievement, performance improvement, bogor 
municipality evaluation upon the economy, efficiency and effectivity has been performed accordingly.

\section{Suggestions}

a. Next researchers who are willingly to continue the same topic, are advised to study other variables which affecting the accountability of authority administration performance such as, the implementation of district financial accountancy, quality control of finance reporting and the transparency of budgeting goals.

b. To study more specific defining the objects of the research, for example, research in a particular administration office, institution or other organization which is under government administration in order to get the result more specific.

c. To distribute on-line questionnaires which is in line with recent digitalized era and to ease the process of questionnaires distribution.

\section{Refference}

Andi (2014) pengaruh perencanaan anggaran, pelaksanaan anggaran, pelaporan / pertanggungjawaban anggaran dan evaluasi kinerja terhadap akuntabilitas instansi pemerintah toba samosir.

Bastian, Indra. (2010). Akuntansi Sektor Publik, Edisi 3, Jakarta: Salemba Empat.

Deputi IV BPKP. (2005). Pedoman Penyusunan Anggaran Berbasis Kinerja (Revisi). Jakarta: BPKP.

Febrina Astria Verasvera (2016) Pengaruh Penerapan Anggaran Berbasis Kinerja Terhadap Kinerja Apratur Pemerintah Daerah (studi kasus pada dinas sosial provinsi jawa barat).

Fazera (2017) Pengaruh Penerapan Anggaran Berbasis Kinerja Terhadap Akuntabilitas Kinerja Instansi Pemerintah perusahaan BUMN PT Pos Indonesia Kota Bandung.

Ghozali, Imam (2016) Aplikasi Analisis Multivariete Dengan Program IBM SPSS 23.

Ida Nur hayati (2014) Pengaruh Penerapan Anggaran Berbasis Kinerja Terhadap Akuntabilitas Kinerja Instansi Pemerintah (Studi Empiris pada Pemerintah Kota Probolinggo).

Indriani Yulia friska (2015) pengaruh penerapan anggaran berbasis kinerja terhadap akuntabilitas kinerja dengan komitmen organisasi sebagai variabel moderating (studi pada satuan kerja perangkat daerah provinsi jambi).

Keputusan Kepala Lembaga Administrasi Negara Nomor 239/IX/6/2003 Tentang Perbaikan Pedoman Penyusunan Laporan Akuntabilitas Kinerja Instansi Pemerintah.

Komang, I Made, Nyoman (2014) Pengaruh Penerapan Anggaran Berbasis Kinerja Terhadap Akuntabilitas Kinerja Instansi Pemerintah (studi kasus pada dinas kehutanan UPT KPH bali tengah kota singaraja).

Luky (2015) pengaruh penerapan anggaran berbasis kinerja terhadap akuntabilitas kinerja intansi pemerintah (studi empiris pada SKPD kabupaten ponorogo).

Mardiasmo. (2018). Akuntansi Sektor Publik Penerbit ANDI. 
The Accounting Journal of BINANIAGA Vol. 04, No. 02, December 2019

p-ISSN: 2527 - 4309, e-ISSN: $2580-1481$

$5^{\text {th }}$ Accreditation Rating: January 14, 2019 - January 13, 2024

Melfariza Sefriyana (2014) pengaruh penerapan anggaran berbasis kinerja terhadap akuntabilitas kinerja instansi pemerintah kota Bengkulu.

Netty Herawati (2016) Pengaruh Kejelasan Sasaran Anggaran, Pengendalian Akuntansi, dan Sistem Pelaporan Terhadap Akuntabilitas Kinerja Instansi Pemerintah Daerah Kota Jambi.

Raissa (2016) Pengaruh Penerapan Anggaran Berbasis Kinerja Terhadap Akuntabilitas Kinerja Instansi Pemerintah Pada Satuan Kerja Perangkat Daerah Kabupaten Magelang.

Safarudin (2018) Pengaruh Penerapan Anggaran Berbasis Kinerja Terhadap Akuntabilitas Kinerja Instansi Pemerintah (Studi Ksus pada Badan Pengelolaan Keuangan dan Aset Daerah Kota Kendari).

Undang-Undang Republik Indonesia Nomor 17 Tahun 2003 tentang Keuangan Negara. Jakarta: Direktorat Jendral Otonomi Daerah.

Undang-Undang Republik Indonesia Nomor 23 Tahun 2014 tentang Pemerintah Daerah. Jakarta: Direktorat Jendral Otonomi Daerah.

Undang-Undang Republik Indonesia Nomor 33 Tahun 2004 tentang Perimbangan Keuangan Antara Pemerintah Pusat dan Pemerintah Daerah. Jakarta: Departemen Kauangan Republik Indonesia.

Wilza, Afrizal, Asep (2014) Pengaruh Penerapan Anggaran Berbasis Kinerja Terhadap Akuntabilitas Kinerja Instansi Pemerintah SKPD kategori dinas di lingkungan Kabupaten Tanjung Jabung Timur dan Kabupaten Muaro Jambi.

Agung Fajar IImiyono. The Effect of Budgeting Based on Performance upon The Accountability of Authority Administration of Bogor Municipality Performance Period 2014-2017 